\title{
Parent Kittiwakes experience a decrease in cell-mediated immunity as they breed
}

\author{
Juli Broggi • Magdalene Langset • Bernt Rønning • \\ Jorg Welcker · Claus Bech
}

Received: 16 September 2009/Revised: 8 February 2010/Accepted: 1 March 2010/Published online: 17 March 2010

(C) Dt. Ornithologen-Gesellschaft e.V. 2010

\begin{abstract}
The maintenance of an effective immune system may entail physiological costs only affordable by individuals in good condition. Some species, like Blacklegged Kittiwakes (Rissa tridactyla) in the high arctic, experience important physiological changes during breeding in order to fulfil their reproductive goals. We studied the effects of breeding effort on the cell-mediated immunity (CMI) of adult breeding Kittiwakes. Parent Kittiwakes showed a significant decrease in CMI from hatching to 15 days into the chick-rearing period, when both parents are known to experience a drastic increase in energy expenditure together with important physiological adjustments. Despite being a long-lived species with biparental care, parent Kittiwakes at the northern border of their breeding range, seem to experience important reproductive immunosupression, even during favourable breeding years.
\end{abstract}

Keywords Costs of reproduction - Immunocompetence PHA · Phytohemagglutinin - High arctic - Rissa tridactyla

Communicated by P. H. Becker.

\section{J. Broggi}

Department of Biology, Oulu University, 90014 Oulu, Finland

M. Langset · B. Rønning · C. Bech

Department of Biology, Norwegian University of Science

and Technology, 7491 Trondheim, Norway

J. Welcker

Norwegian Polar Institute, Polar Environmental Center,

9296 Troms $\varnothing$, Norway

J. Broggi $(\bowtie)$

Estación Biológica Doñana, CSIC, Avda. Americo Vespucio s/n, 1092 Sevilla, Spain

e-mail: juli@ebd.csic.es

\section{Introduction}

As predicted by life history theory, individuals adjust their breeding effort in order to maximise their fitness reward (Stearns 2000). Accordingly, long-lived bird species are often confronted with trade-offs between their own survival and reproduction in the allocation of resources. The maintenance of an effective immune system is critical for adult survival, but involves important physiological costs (Harshman and Zera 2007; Norris and Evans 2000; Sheldon and Verhulst 1996). Immunocompetence can be understood as a surrogate estimation of general parasite resistance of an organism, and the ability to minimise the fitness costs of an infection. The vertebrate immune system comprises diverse components that interact in a complex way, one of these components being acquired cell-mediated immunity (CMI) (Kennedy and Nager 2006; Tella et al. 2008).

Some studies suggest that immunocompetence is costly, and that stressful situations such as heavy workload can compromise the immune response (Bonneaud et al. 2003; Hanssen et al. 2005; Knowles et al. 2009). For example, food manipulation experiments have shown that immunocompetence can be negatively affected by limited resources (Alonso-Alvarez and Tella 2001; Gasparini et al. 2006). On the other hand, some studies have demonstrated that the costs, in terms of nutrients or energy, of building and maintaining an immune defence are probably not large enough to induce a trade-off, suggesting that other factors may regulate immunocompetence (e.g. avoidance of immunopathology) (Hanssen et al. 2004; Nilsson et al. 2007; Råberg et al. 1998; Speakman 2005). However, despite the fact that the immune response may not involve severe direct energetic costs, it may still have non-trivial effects on individuals' life-history strategies (Martin et al. 2003, 2006; Ots et al. 2001). 
Many studies of ecological immunology on breeding individuals have focused on the immune response of offspring exposed to different levels of stress (Gasparini et al. 2006; Sheldon and Verhulst 1996; Soler et al. 2003). However, parents are the ones paying most of the costs of unsuitable breeding conditions, especially in capital breeding and short-lived species, from which comes most evidence on wild populations (Ardia 2005; Morales et al. 2004; Moreno et al. 1999; Nordling et al. 1998). Costs of reproduction on immunocompetence have been demonstrated in incubating females of long-lived species like the Common Eider (Somateria mollissima) during a period of fasting which is known to potentially have long-lasting costs (Bourgeon et al. 2006; Hanssen et al. 2005). Studies on parent immunocompetence have often focused on breeding females, since in many cases they are solely responsible for incubation and brooding, and thus are expected to be more constrained than their partners in resources that could be potentially traded-off against immunocompetence (Cichon et al. 2001; Ilmonen et al. 2002; Merino et al. 2006; Moreno et al. 1999; Nordling et al. 1998). However, information from long-lived species where the costs of reproduction are equally shared between parents is scant.

The Black-legged Kittiwake (Rissa tridactyla) is a longlived medium-sized seagull species having a northern hemisphere circumpolar distribution. It is a semi-precocial species where nestlings require a high degree of parental care (Golet et al. 2000). Chicks are normally brooded until 15 days of age (Moe et al. 2002), and are totally dependent on their parents during the first 6-8 days as they are unable to thermoregulate (Barrett 1978). Chicks fledge at an age of 5-6 weeks and regularly return to the nest after that as they still depend on the parents for food (Cam et al. 2003). Such long-lasting parental dependence, as opposed to precocial species, e.g. eiders, imposes important physiological challenges to parent Kittiwakes. Furthermore, parental duties are shared between parent Kittiwakes (Fyhn et al. 2001), suggesting that costs of reproduction may be traded differently compared to species with different degrees of investment between the sexes.

Previous studies have demonstrated that adult Kittiwakes suffer from a considerable reduction in body condition from hatching until the end of the chick-rearing period, when chicks are around 15 days of age. During this period, parental duties change from incubating to brooding and food-provisioning, and the parents total energy expenditure increases by $24 \%$ (Moe et al. 2002). Despite this considerable increase in energy expenditure, their body mass and basal metabolic rate decreases significantly, suggesting that birds depress certain physiological functions (possibly related to digestive efficiency) in order to fulfil their parental role (Bech et al. 2002; Langseth et al. 2001; Moe et al. 2002; Rønning et al. 2008).
In the present study, we investigated if parent Kittiwakes do experience changes in their cell-mediated immunocompetece parallel to their temporal reallocation of energy from self-maintenance to chick rearing.

\section{Methods}

Study area

The Kittiwakes were studied during the breeding season of 2005 at two breeding sites in Kongsfjorden, on the west coast of Spitsbergen, Svalbard $\left(78^{\circ} 54^{\prime} \mathrm{N}, 12^{\circ} 13^{\prime} \mathrm{E}\right)$. Basic breeding data (clutch size, hatching date and success, and fledging date and success) were collected by regular inspections of the nests throughout the breeding season, which lasts from mid-June to mid-August. Hatching date (day 0 ) of a nest was defined as the date on which the first egg hatched, and all subsequent events were related to this date.

\section{Bird manipulation}

A total of 36 adult Kittiwakes (16 males and 20 females) from 28 nests were used in the present study. The birds were caught at the nests by means of a telescopic fishing rod with a nylon snare fitted to its end. Birds were banded if caught for the first time, and body mass (to the nearest $5 \mathrm{~g}$ with a spring balance; Mess und Wiegetechnik, Wennigsen, Germany), and skull, tarsus and wing lengths were measured; see Moe et al. (2002) for details on the measurement and sexing procedures. Individuals were marked according to their sex with non-permanent ink that lasted for about 1 week, so individuals from each nest could be selectively recaptured.

\section{Measurement of cell-mediated immunity (CMI)}

The phytohemagglutinin (PHA)-injection assay was used to evaluate CMI in vivo following the simplified protocol of Smits et al. (1999). PHA is a non-pathogenic mitogen of plant origin used to stimulate an unspecific immune response, which is commonly used as an index of cellmediated immunity (Kennedy and Nager 2006; Tella et al. 2008). Each individual was challenged once by subcutaneous injecting $50 \mu \mathrm{l}$ of $1 \mathrm{mg} / \mathrm{ml}$ PHA (Sigma, St. Louis, Missouri) in phosphate-buffered saline (PBS) in the wing web (patagia). The thickness of the wing web was measured (to the nearest $0.01 \mathrm{~mm}$ ) with a digital micrometer (Mitutoyo, Tokyo, Japan) at the injection site just prior to and approximately $24 \mathrm{~h}$ after challenge. Because time between measurements varied slightly between individuals, due to the fact that any given individual could not be 
recaptured at an exact time, time from immune challenge to measurement was used as a covariate in all statistical analyses. Swelling of the wing web (i.e. CMI) was calculated as the difference in wing web thickness prior to and $24 \mathrm{~h}$ after injection. The repeatability (Lessells and Boag 1987 ) of our measurements of patagia thickness was very high $(R=0.968, P<0.0001$; based on 36 individuals measured 5 times) and therefore mean values were used in the analyses. Birds were separated in two groups according to the phase of their breeding cycle. The first group included individuals that were challenged around the day their chicks hatched (hereafter around hatching group, $\mathrm{AH})$. The second group included individuals that were challenged around day 14, when brooding duties finalise (hereafter post-brooding group, PB). Details of breeding characteristics and parental profiles of both groups are shown in Table 1.

\section{Statistical analyses}

We studied which factors explained variation in CMI response by means of a general linear model, with breeding stage group and sex as categorical predictors, body mass at the time of immune challenge, and time between measurements as a continuous predictor. We succeeded in measuring CMI of both parents only in eight nests. To explore the association of CMI response between members of a same pair, we ran a separate GLM with all other predictors except sex, but including nest as a random effect. As nest did not explain any significant part of the variation among the subsample $\left(F_{6,6}=0.692, P=0.667\right)$, we did not include nest as a factor in our final analyses. Reproductive and morphological differences between breeding stage groups were assessed beforehand, and removed from later analyses in order to improve statistical power (Table 1). We conducted all the statistical analyses with Statistica 6.0 (Statsoft, Tulsa, OK, USA). All statistical tests are two-tailed.

\section{Results}

Parental characteristics and breeding parameters from both breeding stage groups did not differ, except for body mass that declined significantly (Table 1). The CMI of parent Kittiwakes measured at 14 days of the chick-rearing period was significantly lower than the CMI measured at hatching $\left(F_{1,30}=4.516, P=0.041 ;\right.$ Fig. 1$)$. This decline occurred equally in both sexes $\left(F_{1,30}=0.150, P=0.701\right)$, and independently of body mass $\left(F_{1,30}=0.056, P=0.815\right)$. Furthemorer, time elapsed $(<48 \mathrm{~h})$ between PHA injection and measurements of wing web swelling did not affect CMI measurements $\left(F_{1,30}=2.283, P=0.141\right)$.

\section{Discussion}

Despite being a long-lived seabird, Kittiwakes appear to pay important physiological costs of reproduction. A previous study in the same population showed that body mass and body condition decreased during the chick-rearing period (Moe et al. 2002). We expand these results by showing that CMI also decreases from the incubation to the end of the chick-rearing period.

The high arctic environment imposes strong selective pressures on the reproductive strategies of seabirds. First, adequate environmental conditions to breed may last for only few weeks, with failure to synchronise the breeding attempt being fatal. Secondly, breeding success may vary drastically between years due to the fluctuating nature of the arctic sea environment and the related changes in prey abundance. In this scenario, and considering that 2005 was
Table 1 Breeding information and parental characteristics of the two groups of Black-legged Kittiwakes (Rissa tridactyla) considered in the study. Average sampling day for each group is presented (hatching day $=0$ ). Mean values and corresponding standard error
(SE) are presented, with corresponding sample sizes ( $n$ ), except when stated otherwise. Differences between groups are tested by means of $t$ tests with the corresponding degrees of freedom in parentheses and $P$ values

\begin{tabular}{|c|c|c|c|c|c|c|}
\hline & \multicolumn{2}{|c|}{ Around hatching (AH) } & \multicolumn{2}{|c|}{ Post-brooding (PB) } & \multirow[t]{3}{*}{$t(d f)$} & \multirow[t]{3}{*}{$P$} \\
\hline & \multicolumn{2}{|c|}{ Day $=-1( \pm 2$ days $)$} & \multicolumn{2}{|c|}{ Day $=14( \pm 4$ days $)$} & & \\
\hline & Value & $n$ & Value & $n$ & & \\
\hline Clutch size & $2.0 \pm 0.0$ & 14 & $1.9 \pm 0.5$ & 22 & $0.64(34)$ & 0.52 \\
\hline Average hatching date (July) & $9.9 \pm 1.08$ & 13 & $8.8 \pm 0.55$ & 22 & $1.01(33)$ & 0.32 \\
\hline Body mass (g) & $433.14 \pm 10.09$ & 14 & $382.27 \pm 9.25$ & 22 & $3.45(34)$ & $<0.01$ \\
\hline Wing length (mm) & $319.07 \pm 2.72$ & 14 & $315.69 \pm 1.54$ & 22 & $1.15(31)$ & 0.26 \\
\hline Tarsus (mm) & $34.72 \pm 0.48$ & 14 & $34.15 \pm 0.49$ & 22 & $0.79(34)$ & 0.44 \\
\hline Proportion of males in the sample (\%) & $50 \%$ & 14 & $41 \%$ & 22 & & \\
\hline Time between measurements (h) & $23.4 \pm 0.40$ & 14 & $23.7 \pm 0.80$ & 22 & $-0.39(34)$ & 0.70 \\
\hline
\end{tabular}




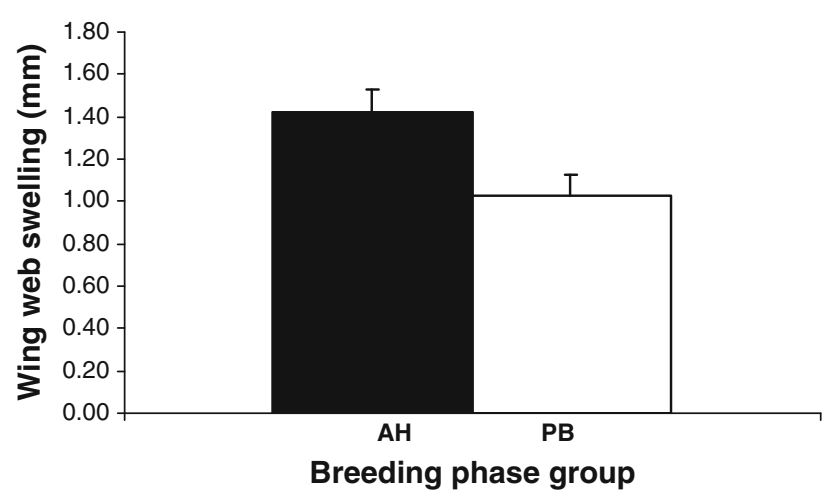

Fig. 1 Cell-mediated immunocompetence measured as wing web swelling in two groups of adult Black-legged Kittiwakes (Rissa tridactyla) at different stages of the breeding cycle. Group $A H$ includes individuals challenged around day of hatching. Group $P B$ includes individuals challenged around day 14 after hatching, when the intensive brooding phase ends

a good year in terms of breeding performance and environmental conditions (Moe et al. 2009), the fact that both parent sexes incurred a reduction in CMI implies that such costs could be even higher in years with less favourable breeding conditions.

Costs of reproduction in long-lived birds had previously been found in Common Eiders, where parental roles are quite different, as only females are in charge of the offspring, and chicks are almost self-sufficient upon hatching (Hanssen et al. 2005). Despite being a long-lived species, the fact that both parent Kittiwakes invest similarly in breeding and still experience important physiological costs suggests that the reproduction in this species in high arctic conditions is highly constrained.

Interestingly, it could be argued that adult birds could afford depressing immune functions during breeding without incurring real costs (Piersma 1997). High arctic populations suffer from low parasitic pressure, as insect vectors and ectoparasites are not common in these high latitudes (McCoy et al. 2005; Staszewski et al. 2007). However, other factors than vector-borne diseases, such as intestinal parasites which can be acquired from food, are also known to have a strong impact on avian populations (Clayton and Moore 1997). Additionally, considering that Kittiwakes are a long-lived species (3-4 years to return to the breeding places and start breeding), and that the potential transmission with individuals from other colonies exposed to parasites is possible, it is not likely that birds suppress immune function adaptively as a consequence of low-parasite exposure. In any case, deciding whether parent Kittiwakes adjust their immune system adaptively, or suffer immunosuppression as a result of breeding costs, would require an experimental approach to disentangle both explanations for our results.
In the present study, we have reported a decline in CMI in breeding parent Kittiwakes, as found previously in parents from other long-lived species, but with asymmetric parental roles (e.g. Bourgeon et al. 2006). These results highlight the levels of physiological stress that this species needs to endure in order to reproduce. Because the results were obtained during a "good breeding" year, the effects may presumably be even more important under less favourable breeding conditions. Due to the energetic constraints imposed on these border populations, susceptibility to changes in climate inducing variations in prey availability, breeding conditions and parasite burdens may be extremely high, and thus require careful and constant monitoring.

\section{Zusammenfassung}

Dreizehenmöweneltern erfahren während des Brütens eine Abnahme der zellvermittelten Immunität

Die Aufrechterhaltung eines effektiven Immunsystems könnte physiologische Kosten mit sich bringen, die sich nur Individuen in guter Kondition leisten können. Einige Arten, wie z.B. Dreizehenmöwen (Rissa tridactyla) in der Hocharktis, erfahren während des Brütens wichtige physiologische Veränderungen, um ihre Fortpflanzungsziele zu erfüllen. Wir haben die Einflüsse des Brutaufwandes auf die zellvermittelte Immunität (CMI) adulter brütender Dreizehenmöwen untersucht. Dreizehenmöweneltern zeigten eine signifikante Abnahme der CMI vom Schlupf bis 15 Tage in die Kükenaufzuchtsphase hinein, wenn beide Eltern einen drastischen Anstieg im Energieaufwand nebst wichtigen physiologischen Anpassungen erfahren. Obwohl diese Art langlebig ist und beide Eltern Brutpflege betreiben, scheinen Dreizehenmöweneltern am nördlichen Rand ihres Brutgebietes wichtige reproduktive Immunsuppression zu erfahren, selbst in günstigen Brutjahren.

Acknowledgments Permission to carry out the study in the Kittiwake colonies was provided by the Governor of Svalbard (Sysselmannen; ref. 2004/00884-4 a522-01), while permission to perform the PHA injections was given by the Norwegian National Animal Research Authority (Fors $\varnothing$ ksdyrutvalget; ref. 2005/20577). J.B. was funded by EC Marie Curie EVK1-CT-2002-57003 fellowship, while B.R., C.B. and M.L. were funded by Norwegian Polar Institute. Thanks are due to to the staff at Kings Bay and Norsk Polarinstitutt for logistic support. We also thank Geir Wing Gabrielsen and Olivier Chastel for help during the field season. We are indebted with Jordi Figuerola for his valuable comments on previous versions of the manuscript.

\section{References}

Alonso-Alvarez C, Tella JL (2001) Effects of experimental food restriction and body-mass changes on the avian T-cell-mediated immune response. Can J Zool 79:101-105 
Ardia DR (2005) Individual quality mediates trade-offs between reproductive effort and immune function in tree swallows. J Anim Ecol 74:517-524

Barrett RT (1978) Adult body temperatures and the development of endothermy in the kittiwake (Rissa tridactyla). Astarte 11:113116

Bech C, Langseth I, Moe B, Fyhn M, Gabrielsen GW (2002) The energy economy of the arctic-breeding kittiwake (Rissa tridactyla): a review. Comp Biochem Physiol A 133:765-770

Bonneaud C, Mazuc J, González G, Haussy C, Chastel O, Faivre B, Sorci G (2003) Assessing the cost of mounting an immune response. Am Nat 161:367-380

Bourgeon S, Criscuolo F, Le Maho Y, Raclot T (2006) Phytohemagglutinin response and immunoglobulin index decrease during incubation fasting in female common eiders. Physiol Biochem Zool 79:793-800

Cam E, Monnat JY, Hines JE (2003) Long-term fitness consequences of early conditions in the kittiwake. J Anim Ecol 72:411-424

Cichon M, Dubiec A, Chadzinska M (2001) The effect of elevated reproductive effort on humoral immune function in collared flycatcher females. Acta Oecologica 22:71-76

Clayton DH, Moore J (1997) Host-parasite evolution. General principles and avian models. Oxford University Press, Oxford

Fyhn M, Gabrielsen GW, Nordøy ES, Moe B, Lagnseth I, Bech C (2001) Individual variation in field metabolic rate of kittiwakes (Rissa tridactyla) during the chick-rearing period. Physiol Biochem Zool 74:343-355

Gasparini J, Roulin A, Gill VA, Hatch SA, Boulinier T (2006) In kittiwakes food availability partially explains the seasonal decline in humoral immunocompetence. Funct Ecol 20:457-463

Golet GH, Irons DB, Costa DP (2000) Energy costs of chick rearing in black-legged kittiwakes (Rissa tridactyla). Can J Zool 78:982-991

Hanssen SA, Hasselquist D, Folstad I, Erikstad KE (2004) Costs of immunity: immune responsiveness reduces survival in a vertebrate. Proc R Soc Lond B 271:925-930

Hanssen SA, Hasselquist D, Folstad I, Erikstad KE (2005) Cost of reproduction in a long-lived bird: incubation effort reduces immune function and future reproduction. Proc R Soc Lond B 272:1039-1046

Harshman LG, Zera AJ (2007) The cost of reproduction: the devil in the details. Trends Ecol Evol 22:80-86

Ilmonen P, Taarna T, Hasselquist D (2002) Are incubation costs in female pied flycatchers expressed in humoral immune responsiveness or breeding success? Oecologia 130:199-204

Kennedy MW, Nager RG (2006) The perils and prospects of using phytohaemagglutinin in evolutionary ecology. Trends Ecol Evol 21:653-655

Knowles SCL, Nakagawa S, Sheldon BC (2009) Elevated reproductive effort increases blood parasitemia and decreases immune function in birds: a meta-regression approach. Funct Ecol 23:405-415

Langseth I, Moe B, Bech C (2001) Reduction in body mass and basal metabolic rate in breeding female black-legged kittiwakes Rissa tridactyla: an adaptation to reduce maintenance costs. Atlantic Seabirds 3:165-178

Lessells CM, Boag PT (1987) Unrepeatable repeatabilities: a common mistake. Auk 104:116-121

Martin LB, Scheuerlein A, Wikelski M (2003) Immune activity elevates energy expenditure of house sparrows: a link between direct and indirect costs? Proc R Soc Lond B 270:153-158

Martin LB, Hasselquist D, Wikelski M (2006) Investment in immune defence is linked to pace of life in house sparrows. Oecologia 147:565-575

McCoy KD, Boulinier T, Tirard C (2005) Comparative host-parasite population structures: disentangling prospecting and dispersal in the black-legged kittiwake Rissa tridactyla. Mol Ecol 14:28252838

Merino S, Moreno J, Tomás G, Martínez J, Morales J, Martínez de la Puente J, Osorno JL (2006) Effects of parental effort on blood stress protein HSP60 and immunoglobulins in female blue tits: a brood size manipulation experiment. J Anim Ecol 75:1147-1153

Moe B, Langseth I, Fyhn M, Gabrielsen GW, Bech C (2002) Changes in body condition in breeding kittiwakes Rissa tridactyla. J Avian Biol 33:225-234

Moe B, Stempniewicz L, Jakubas D, Angelier F, Chastel O, Dinessen F, Gabrielsen GW, Hanssen F, Karnovsky NJ, Rønning B, Welcker J, Wojczulanis-Jakubas K, Bech C (2009) Climate change and phenological responses of two seabird species breeding in the high-arctic. Mar Ecol Prog Ser 393:235-246

Morales J, Moreno J, Merino S, Tomás G, Martínez J, Garamszegi LZ (2004) Associations between immune parameters, parasitism, and stress in breeding pied flycatcher (Ficedula hypoleuca) females. Can J Zool 82:1484-1492

Moreno J, Sanz JJ, Arriero E (1999) Reproductive effort and T-lymphocyte cell-mediated immunocompetence in female pied flycatchers Ficedula hypoleuca. Proc R Soc Lond B 266:11051109

Nilsson J-Å, Granbom M, Råberg L (2007) Does the strength of an immune response reflect its energetic cost? J Avian Biol 38:488494

Nordling D, Andersson M, Zohari S, Gustafsson L (1998) Reproductive effort reduces specific immune response and parasite resistance. Proc R Soc Lond B 265:1291-1298

Norris K, Evans MR (2000) Ecological immunology: life history trade-offs and immune defence in birds. Behav Ecol 11:19-26

Ots I, Kerimov AB, Ivankina EV, Ilyina T, Horak P (2001) Immune challenge affects basal metabolic activity in wintering great tits. Proc R Soc Lond B 268:1175-1181

Piersma T (1997) Do global patterns of habitat use and migration strategies co-evolve with relative investments in immunocompetence due to spatial variation in parasite pressure? Oikos 80:623-631

Råberg L, Grahn M, Hasselquist D, Svensson E (1998) On the adaptive significance of stress-induced immunosuppression. Proc R Soc Lond B 265:1637-1641

Rønning B, Moe B, Chastel O, Broggi J, Langset M, Bech C (2008) Metabolic adjustments in breeding female kittiwakes (Rissa tridactyla) include changes in kidney metabolic intensity. J Comp Physiol B 178:779-784

Sheldon BC, Verhulst S (1996) Ecological immunology: costly parasite defences and trade-offs in evolutionary ecology. Trends Ecol Evol 11:317-321

Smits JE, Bortolotti GR, Tella JL (1999) Simplifying the phytohemagglutinin skin-testing technique in studies of avian immunocompetence. Funct Ecol 13:567-572

Soler JJ, Moreno J, Potti J (2003) Environmental, genetic and maternal components of immunocompetence of nestling pied flycatchers from a cross-fostering study. Evol Ecol Res 5:259272

Speakman JR (2005) Body size, energy metabolism and lifespan. J Exp Biol 208:1717-1730

Staszewski V, McCoy KD, Tvera T, Boulinier T (2007) Interannual dynamics of antibody levels in naturally infected long-lived colonial birds. Ecology 88:3183-3191

Stearns SC (2000) Life history evolution: successes, limitations, and prospects. Naturwissenschaften 87:476-486

Tella JL, Lemus JA, Carrete M, Blanco G (2008) The PHA test reflects acquired t-cell mediated immunocompetence in birds. PLoS ONE 3(9):e3295 